Bryn Mawr College

Scholarship, Research, and Creative Work at Bryn Mawr College

Classical and Near Eastern Archaeology Faculty

Research and Scholarship

Classical and Near Eastern Archaeology

2010

\title{
Revisiting Indian Rouletted Ware and the Impact of Indian Ocean Trade in Early Historic South Asia
}

Peter Magee

Bryn Mawr College, pmagee@brynmawr.edu

Let us know how access to this document benefits you.

Follow this and additional works at: http://repository.brynmawr.edu/arch_pubs

Part of the Classical Archaeology and Art History Commons, and the History of Art, Architecture, and Archaeology Commons

\section{Custom Citation}

Magee, Peter. "Revisiting Indian Rouletted Ware and the Impact of Indian Ocean Trade in Early Historic South Asia," Antiquity 84 (2010): 1043-1054.

This paper is posted at Scholarship, Research, and Creative Work at Bryn Mawr College. http://repository.brynmawr.edu/arch_pubs/147

For more information, please contact repository@brynmawr.edu. 


\section{Revisiting Indian Rouletted Ware and the impact of Indian Ocean trade in Early Historic south Asia}

Peter Magee*

Indian Rouletted Ware pottery is the iconic marker of the overseas reach of the subcontinent at the turn of the first millennium $A D$. In the mid twentieth century this was naturally seen as prompted by the contemporary Roman Empire, while the later post-colonial discourse has emphasised the independence and long life of Indian initiatives. In this new analysis the author demonstrates a more complex socio-economic situation. While Greyware is distributed long term over south India, Rouletted ware is made in at least two regional centres for coastal communities using a new ceramic language, one appropriate to an emerging international merchant class.

Keywords: India, Sri Lanka, Mauryan Empire, Roman Empire, Rouletted ware, IRW, Greyware, Arretine ware, Principal Components Analysis

\section{Introduction}

Although it is now well accepted that there was Indian Ocean trade long before Roman contact (Ray 1994, 2003; Morrison 1997), the influence of Mediterranean trade on ancient south Asia is still a matter of debate. In the last 60 years research on this issue has been played out against a swinging pendulum of academic interest that has now moved solidly into a post-colonial framework. This stands in contrast to earlier modes of thought, particularly those espoused by Wheeler, which are often characterised as emphasising Mediterranean contact as a major stimulus for cultural developments in the subcontinent.

Indian Rouletted Ware (hereafter IRW) and a number of other south Asian fine wares (Type 10, Type 18 and Omphalos ware) have operated as a proxy for these broader issues. As the wares occur around the time of increased Mediterranean contact with south Asia they were initially interpreted as evidence of a deep impact on local material culture production (Wheeler et al. 1946). More recently, several jointly authored papers by Coningham, Ford and Pollard (hereafter Coningham et al.) have argued on the basis of geochemical data that these fine wares were produced in a highly specialised and centralised framework that was embedded within pre-existing modes of production and distribution (Krishnan \& Coningham 1997; Ford \& Coningham 2005; Ford et al. 2005). In so doing, they have

* Department of Archaeology, Bryn Mawr College, 101 North Merion Avenue, Bryn Mawr, PA 19010, USA (Email:pmagee@brynmawr.edu) 
downplayed the influence of Mediterranean contact in favour of an interpretation that emphasises continuity in south Asian economic and social structures.

This paper re-examines the published data on IRW and other south Asian fine wares and suggests that a more nuanced and careful examination of this evidence indicates that the production and consumption of IRW differs considerably from that which had previously existed in south Asia. It is argued that the increasing importance of a powerful and economically successful maritime merchant class is critical to these developments.

\section{Indian Rouletted Ware}

It is now generally accepted that the production of Indian Rouletted Ware dates from the second century BC onwards (Begley 1983, 1988; Schenk 2006). The origin and production of IRW has, however, been debated since Wheeler's publication of his excavations at the south-east Indian port city of Arikamedu (Wheeler et al. 1946). Coningham et al. identify two major theories for understanding the origin of this ware (Krishnan \& Coningham 1997: 925). The first, which they attribute to Wheeler, suggests 'a Roman origin for these wares due to the presence of Arretine ware and amphorae in the same level' (Ford et al. 2005: 911). In fact, Wheeler and those working with him never equated the appearance of IRW with the importation of Arretine ware. In their initial publication of Arikamedu they state that IRW 'both preceded and outlasted the Arretine ware by an appreciable margin' (Wheeler et al. 1946: 46). The second theory, which Coningham et al. attribute to Begley $(1983,1988)$, accepts IRW as a locally produced ceramic but still argues for Mediterranean influence in its decoration. This latter opinion, namely that the rouletting found on IRW does indeed betray Mediterranean, but not necessarily Roman, influence, seems now generally to be accepted by most scholars. As Ray has pointed out, a possible source for this distinctive decoration may have been contact with settlements in the Arabian Gulf, many of which contain imported Hellenistic ceramics (Ray 1994: 75).

The question of where IRW was produced has also been debated. Coningham et al. and Begley suggest an origin in the southern areas of India and Sri Lanka (Begley 1988: 439). Schenk, relying upon limited XRD analysis conducted by Gogte (1997) and fabric similarities with Northern Black Polished Ware, raises the possibility of a northern, Gangetic origin for this ware (Schenk 2006: 136). This supports Schenk's argument that IRW is connected with Mauryan diplomacy and, possibly, the spread of Buddhism. Since XRD examines the mineralogy of ceramics, not their geochemistry, it is not the most sensitive index of production origin over the vast distances of the Indian peninsula. Indeed, there is no reason - or evidence - to support the assertion that there is only one production source for IRW throughout south Asia. Coningham et al.'s suggestion that the IRW found in southern Indian and Sri Lanka is probably produced somewhere in that vicinity is not contradicted by any archaeological evidence.

The location of IRW production within southern India and Sri Lanka remained unexamined until Coningham et al. conducted geochemical analysis on IRW and other fine wares from a number of sites in this area (Krishnan \& Coningham 1997; Ford \& Coningham 2005; Ford et al. 2005). The most detailed publication (Ford et al. 2005) employed inductively coupled plasma-atomic emission spectroscopy and mass spectometry 
to analyse samples from the key sites of Arikamedu and Anuradhapura, a major settlement in Sri Lanka excavated by Coningham (Ford et al. 2005). The purpose of this analysis was to investigate, using chemical analyses of the fabric, whether Rouletted ware, Arikamedu Type 10 and Greyware were produced from a single geological source' (Ford et al. 2005: 911).

Greyware was produced prior to any Mediterranean contact and was probably an elite ceramic that in some way functionally preceded the production of IRW (Krishnan \& Coningham 1997). Coupling its analysis with that of IRW permitted Coningham et al. to approach the production and consumption of both of these wares through the period in which Mediterranean contact with south Asia increases. On the basis of this geochemical analysis, Coningham et al. concluded that:

$\therefore$. the majority of the fine wares analysed (Greyware, Rouletted ware, Arikamedu Types 10 and 18 and Omphalos) came from the same or a set of closely related geological sources. ... A most important result is that Greyware is sufficiently similar to the other fine wares to suggest a similar provenance. It appears that all the fine wares were not only made from the same geological material, but also produced in consistent fabric over a long period of time (c. $500 \mathrm{BC}-\mathrm{AD}$ 200)... . This points to a single long-running major ceramic production centre' (Ford et al. 2005: 918).

The geochemical similarities to Greyware therefore provide the basis for the compelling argument that IRW production was embedded within existing economic systems and was thus unaffected by increased contact with the Mediterranean from the second century BC.

There are, however, several internal inconsistencies in the body of research published by Coningham et al. that make this model problematic. In a paper published in 1997, Krishnan and Coningham presented the results of detailed thin-section analysis of a small number of sherds from Anuradhapura.The later geochemical work does not refer directly to these results but rather claims:

...thin section analysis by Khrishnan and Coningham has demonstrated clear relationships between Rouletted ware and Greyware at Anuradhapura and also between Rouletted ware from Anuradhapura and Arikamedu, therefore indicating both temporal and spatial similarities (Krishnan and Coningham 1997)' (Ford \& Coningham 2005: 394).

This paraphrasing of earlier results by some of the same researchers is actually at odds with the conclusions of the original publication. Krishnan and Coningham's published mineralogical analysis was conducted on sherds from Anuradhapura only, not Arikamedu, and it would be a somewhat gymnastic rendering of that analysis to support the existence of 'temporal and spatial similarities' in the production of fine wares. In fact, Krishnan and Coningham (1997) state clearly that:

$\therefore$ the textual similarities in coarse wares (Fabric $A$ and A1) and fine wares (Fabric $B, B 1$ and B2) point to a similar technology for each variety (Shah 1994), however, the mineralogical differences within the fine wares may indicate separate clay sources' (Krishnan \& Coningham 1997: 934). 
In their desire to characterise IRW and other south Asian fine wares as products of a single specialised production centre that was unaffected by Mediterranean contact, Coningham et al. are adhering to a master narrative that dominates discussions of south Asia's relations with the Mediterranean and Middle East. This master narrative views all economic, social and political developments within south Asia as purely autochthonous in nature. On the one hand, there can be little doubt that archaeological fieldwork conducted since 1947 in south Asia has done much to illuminate the powerful indigenous economic, social and religious forces that contoured ancient south Asian society. On the other hand, to deny the potentially important role that south Asia's external contacts played in shaping material culture production, is to deny agency to a landmass that lies at the centre of the Indian Ocean world. In the case of IRW, Coningham et al. have overlooked the possibility that fine ware production was neither subsumed by, nor totally resilient to, the economic changes brought about by contact with the Mediterranean.

The publication of geochemical data on IRW and other fine wares provides an opportunity to re-investigate these issues more carefully and to move away from reductionist interpretations that do little to illuminate what were undoubtedly complex interactions between the Mediterranean and Indian Ocean in both directions.

\section{Re-evaluating the geochemical data on IRW}

Coningham et al.'s conclusion that all the fine wares, including IRW, Grey, Arikamedu Type 10, Arikamedu Type 18 and Omphalos wares, were the products of a single, pre-existing production centre (Ford et al. 2005: 918) is based on a standard multivariate technique, Principal Components Analysis (PCA), of a subset of the geochemical data. The PCA was conducted only on the elements obtained by AES. These exclude most of the Lanthanides obtained by mass spectrometry (Ford et al. 2005, online supplement).

The dataset includes samples of south Asian fine wares from Arikamedu and Anuradhapura; coarse wares from Anuradhapura, Mantai and Arikamedu; and local clays and modern ceramics from Anuradhapura. According to Coningham et al., a bi-variate plot of the first two principal components (Ford et al. 2005: fig. 3) seems to indicate that all the south Asian fine wares, including IRW and Greyware, are geochemically homogenous and different from the Sri Lankan coarse wares. This conclusion, however, ignores the fundamental purpose of PCA in assessing relative variation within a dataset. Although the PCA analysis does indicate that south Asian fine wares are geochemically different from coarse wares or modern ceramics from Anuradhapura, it does not necessarily suggest that the vast majority of the archaeological fine ware and Greyware samples are all from a similar provenance' (Ford et al. 2005: 913).

As noted in Coningham et al.'s earlier work, the coarse wares from Anuradhapura are very different in their mineralogy from other south Asian fine wares (Krishnan \& Coningham 1997). Too little has been researched on Sri Lankan coarse wares to determine if these mineralogical differences reflect different parent clays or the anthropogenic alteration, or different tempering, of clay. Regardless, within the framework of a multivariate analysis, the inclusion of such different coarse wares creates a statistical structure that makes the other ceramics look more similar to each other than they would if those coarse ware samples were 


\section{Peter Magee}

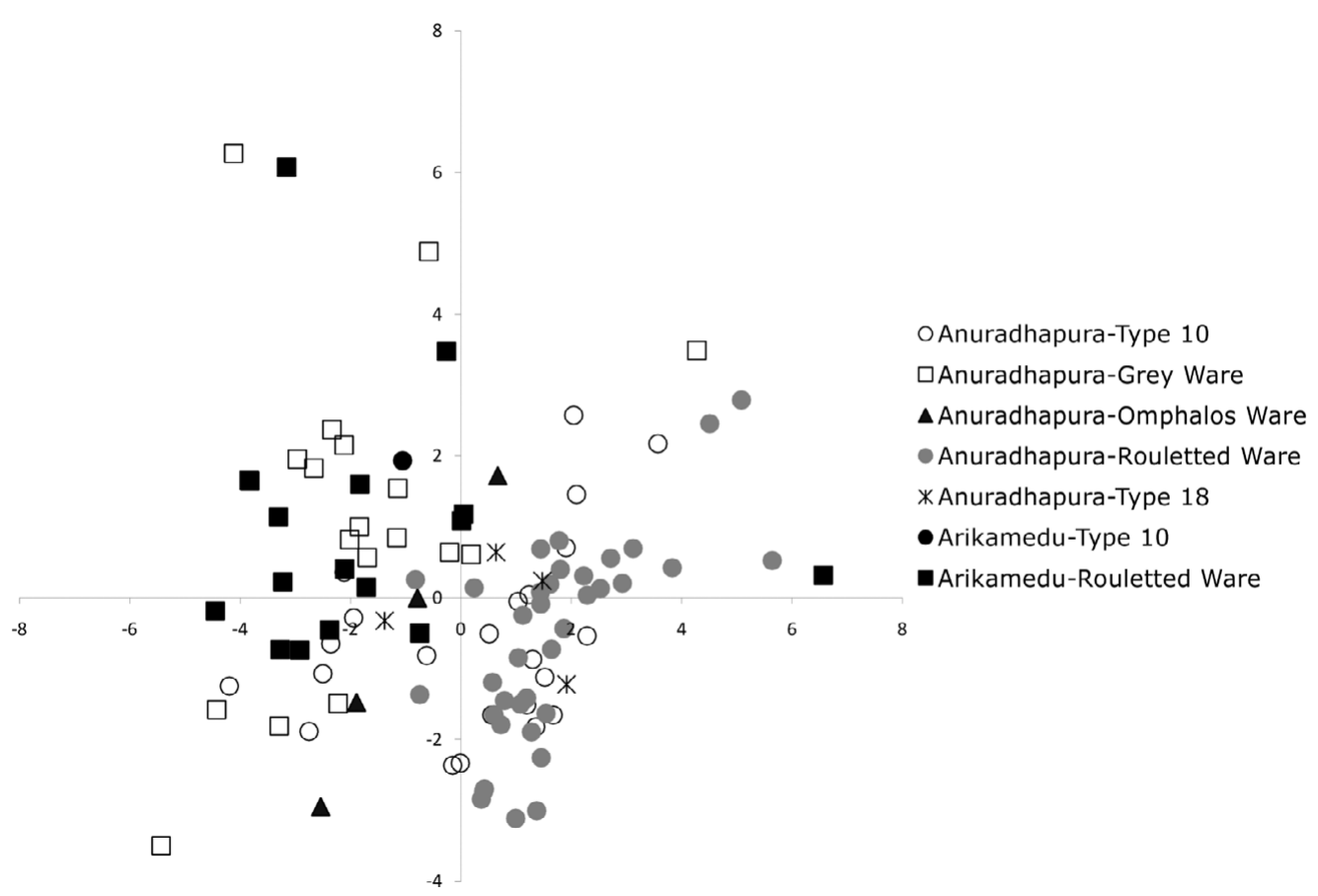

Figure 1. PCA of raw elemental data. First two principal components account for 40 per cent of dataset variation.

excluded. Put simply: all the fine wares look more similar to each other than do any of them to the coarse wares.

Given that Coningham et al.'s goal was to 'investigate, using chemical analyses of the fabric, whether Rouletted ware, Arikamedu Type 10 and Greyware were produced from a single geological source' (Ford et al. 2005: 911), it would seem that the best approach would be to limit first analysis to samples of these wares from the major sites of Arikamedu and Anuradhapura. In doing so, the statistical effect created by the inclusion of the mineralogically different coarse wares is countered.

A new Principal Components Analysis of this data suggests a broadly similar characterisation for all these fine wares (Figure 1). However, even within this relatively homogenous dataset the new PCA suggests the existence of subtle but very important groupings. Both the Greyware from Anuradhapura and the IRW from Arikamedu exhibit uniformity in their composition and cluster on the negative side of the $\mathrm{x}$-axis. Both these groups are differentiated from the IRW at Anuradhapura that clusters on the positive side of the $x$-axis. Type 10 fine wares appear on the whole to cluster with this latter group, although some are found with the former.

The correlation between the visually identified classes of ceramics and the statistical clustering raises the possibility of two distinct workshop traditions: one producing Greyware and the IRW found at Arikamedu, and the other producing the IRW found at Anuradhapura. Both workshop traditions may have been involved in the production of Type 10 fine wares. 
The clay used in these production centres was acquired near the highly active rivers found alongside Arikamedu and/or Anuradhapura. It is possible, therefore, that some of the variation unaccounted for by the first two principal components reflects natural weathering in clays typical of such environments. Recently, researchers analysing ceramic production in a riverine system in Portugal utilised Scandium-normalisation to produce greater clarity in the geochemical analysis of such clays (Dias \& Prudêncio 2008; Prudêncio et al. 2009). The efficacy of this approach was also demonstrated by analysing Roman amphorae from three known kiln sites in the Tagus basin and Sado River areas. Principal Components Analysis of the raw elemental data suggested only two geochemical groupings whereas Principal Components Analysis of the Scandium-normalised data produced three clusters that correlated with the three known production centres (Dias \& Prudêncio 2008; Prudêncio et al. 2009).

Although there is still much research to be done on such approaches to archaeological geochemistry - and such an approach cannot be guaranteed to enhance analysis in all situations - this technique proved very useful for the fine ware geochemical dataset. The first two principal components of the Scandium-normalised data account for 66.3 per cent of dataset variation, a more than 50 per cent increase from the PCA of the raw elemental data. A scatterplot of the first two principal components not only shows tighter clustering within the formally defined groups of IRW and Greyware but also confirms the clustering of IRW from Arikamedu with the Greywares from Anuradhapura and the distinctive nature of IRW from Anuradhapura (Figure 2).

Inasmuch as geochemical data may reflect discrete production centres, this analysis suggests two possible production centres for the south Asian fine wares (Table 1). Group A consists of the IRW from Arikamedu and the Greyware from Anuradhapura, while Group $\mathrm{B}$ comprises the IRW found at Anuradhapura. Both centres appear to be engaged in the production of Type 10 ceramics.

A detailed analysis of the provenance of the analysed ceramics suggests that there is also a previously unrecognised chronological facet to these two groups. The majority of analysed Greyware sherds that define Group A date to before Anuradhapura Phase G (dated 200 BC$\mathrm{AD}$ 130), that is before the period during which large-scale direct maritime contact with the Mediterranean occurred (Figure 3). By contrast, the vast majority of IRW samples that define Group B date to Anuradhapura Phase G and later, thus placing them in the period during which maritime contact with the Mediterranean is thought to have been flourishing. This chronological facet of production is critical to understanding the production of south Asian fine wares and I will return to it below.

\section{Where was production located? The europium anomaly and the source of south Asian fine wares}

Rare Earth Element (REE) data are an important feature of Coningham et al.'s research and have the potential to illuminate the basic geochemistry of the clay used in the production of both fine and coarse wares. Coningham et al. argue that REE concentrations point to an Indian, rather than a Sri Lankan, origin for all south Asian fine wares, including Greyware 


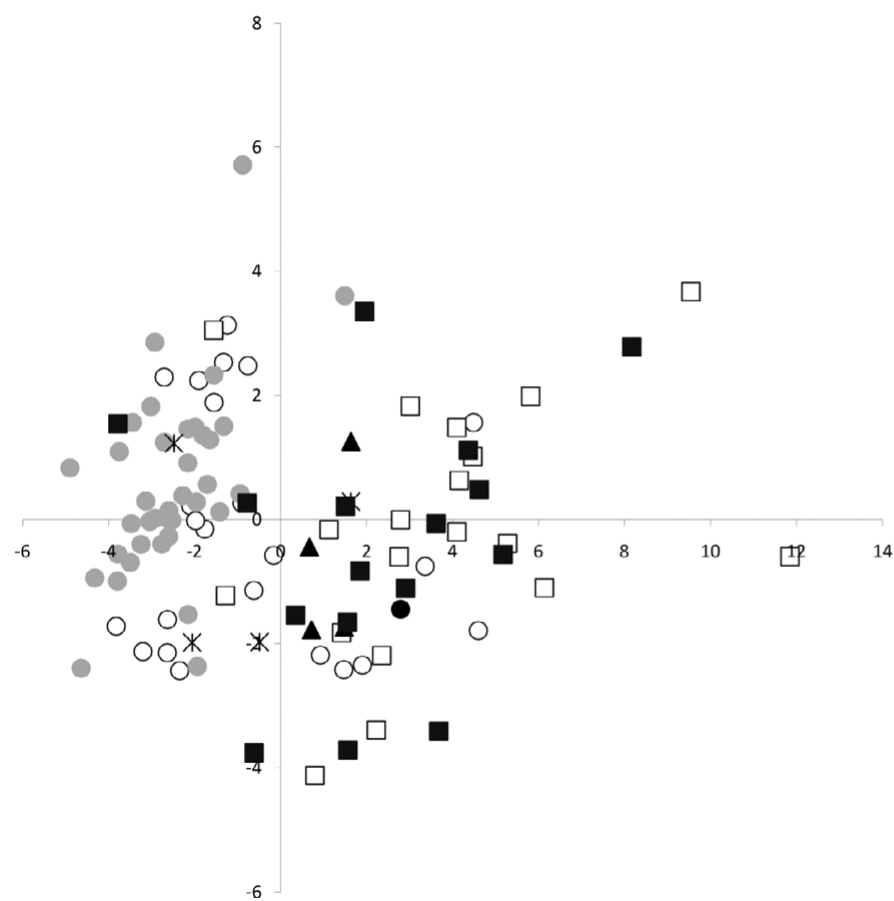

O Anuradhapura-Type 10

$\square$ Anuradhapura-Grey Ware

^Anuradhapura-Omphalos Ware

- Anuradhapura-Rouletted Ware

* Anuradhapura-Type 18

- Arikamedu-Type 10

-Arikamedu-Rouletted Ware

Figure 2. PCA of Scandium-normalised data. First two principal components account for 66.3 per cent of dataset variation.

Table 1. Summary of south Asian fine ware production groups.

\begin{tabular}{lcc}
\hline & Group A & Group B \\
\hline Ceramic types & Greyware (Anuradhapura) Type 10 & IRW (Anuradhapura) \\
& (Anuradhapura) IRW (Arikamedu) & Type 10 (Anuradhapura) \\
Location of production & South-eastern India (?) & Sri Lanka near Anuradhapura (?) \\
Chronology & $\boldsymbol{c} .500$ BC-AD 300 & $c$. after 200 BC-AD 300 \\
\hline
\end{tabular}

(Ford et al. 2005: 918). To do this they focus on the europium (Eu) anomaly, which is generally regarded as a sensitive index of geological origins. They conclude that:

$\therefore$.. all the REE profiles discussed above (i.e. those of fine and Greywares) display a significant negative europium anomaly (i.e. there is less europium in the sample than would be predicted from the other REE abundances). Four of the six coarse wares analysed from Anuradhapura do not demonstrate a negative europium anomaly, whereas the single samples of coarse wares from Arikamedu, Kantarodai and Mantai do show a negative anomaly (as do two of the six from Anuradhapura, of course). The evidence is equivocal, but suggests on balance that Anuradhapura is not the source of the clay used to manufacture the fine wares discussed in this article' (Ford et al. 1995: 917).

Chondrite-normalised plots are presented in support of this assertion.

Coningham et al. appear to have assessed the Eu anomaly on the difficult-to-see visual representation of the chondrite-normalised plots rather than the calculation of the 


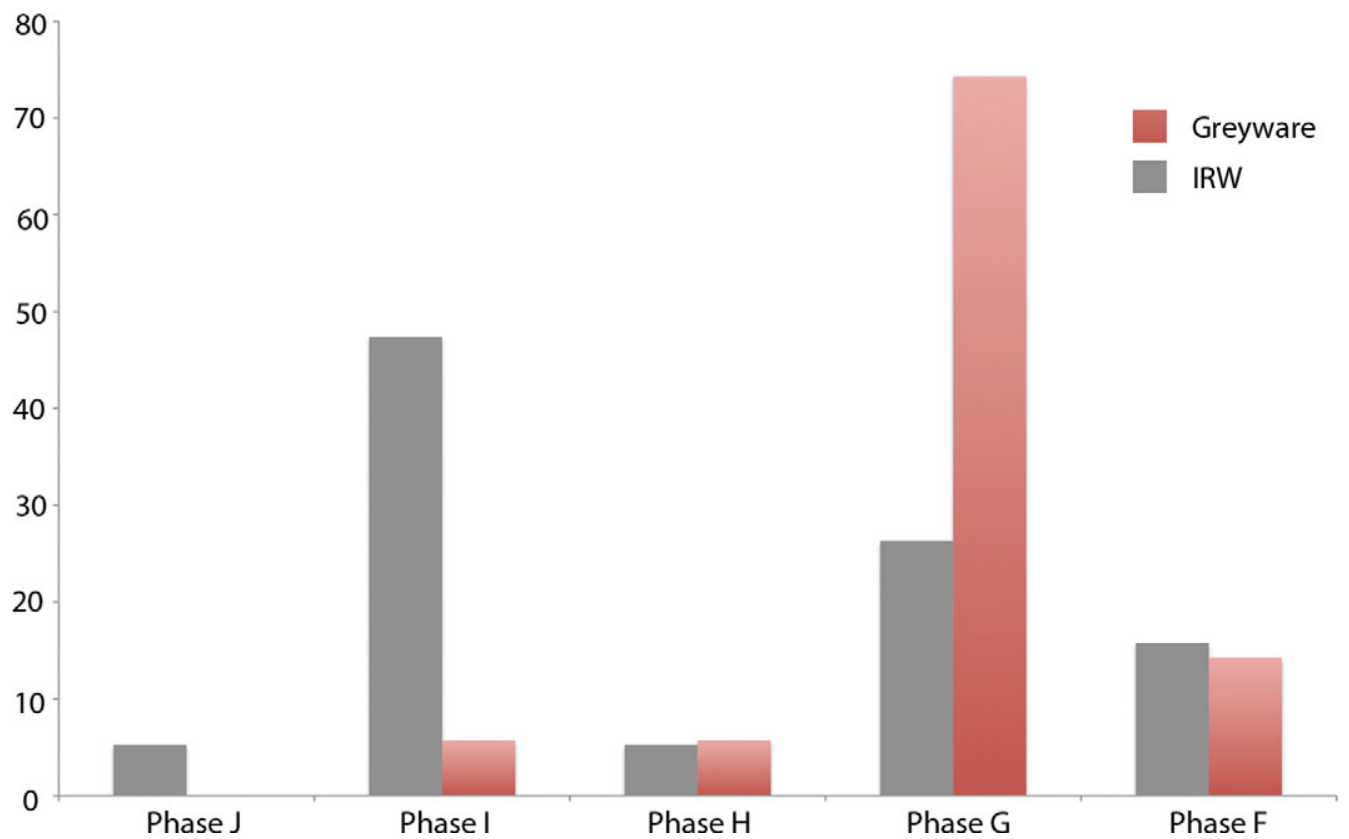

Figure 3. Percentages of sampled ceramics in the Anuradhapura sequence (after Ford et al. 2005).

normalised value of Eu divided by its normalised theoretical level (i.e. Eu/ $\sqrt{ }\left(\mathrm{Sm}^{*} \mathrm{Gd}\right)$ ). In Figure 4, we have plotted the chondrite-normalised value of Eu against its theoretical level. Contrary to Coningham et al.'s arguments, all but one of the sampled ceramics has a negative $\mathrm{Eu}$ anomaly (i.e. $\mathrm{Eu} / \mathrm{Eu}^{*}<1$ ). Furthermore, four of the eight coarse ware samples from Sri Lanka (two from Anuradhapura, one from Mantai and one from Kantarodai) cluster with the fine wares from both south Indian and Sri Lankan sites. In addition, several of the fine ware samples from Arikamedu are outliers from the main fine ware group and exhibit $\mathrm{Eu} / \mathrm{Eu}^{*}$ values that are closer to four of the coarse ware samples from Anuradhapura. In short, there seems little correlation between known geographical origin and the assessed europium anomaly. Potential measurement problems are also suggested by the one sample (no. 111) for which repeat REE values are reported. One value (.64) for this sample is within the normal range for the dataset while the other (.75) is close to the 'outlier' range. In conclusion, assessment of the Eu anomaly does not hold the potential to discriminate the location production for the analysed dataset of south Asian fine wares.

Although the geochemical evidence does not help in determining the location for these production centres there is circumstantial archaeological evidence that Greyware - a defining component of Group A - was produced on the Indian mainland (Ford et al. 2005: 917). The fact that nearly all of the sherds from Arikamedu also fall within this group makes it likely that Group A was produced somewhere in south-eastern India. Group B consists solely of sherds from Anuradhapura. As noted above, there is nothing in the geochemical data that rules out ceramic production in Sri Lanka and in the absence of any firmer evidence, we hypothesise that Group B is produced somewhere in Sri Lanka, probably in the northern 


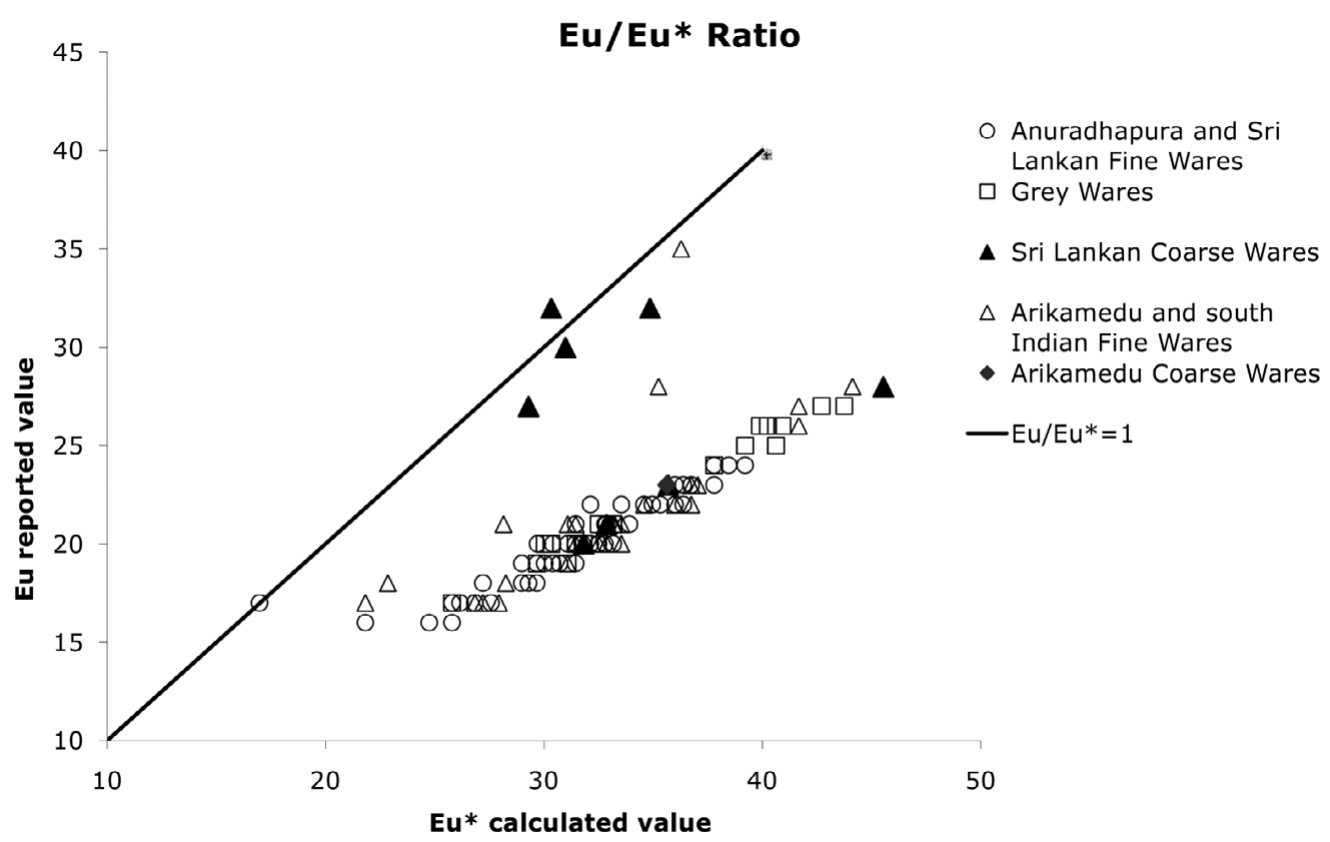

Figure 4. Bivariate plot of Eu and Eu*values for analysed ceramics.

part of the island. Only further geochemical analysis and archaeological research can confirm or refute this hypothesis.

Combining the chronological, geochemical and archaeological data together suggest, therefore, that Greyware and IRW have distinct chronological and distributional characteristics.

\section{Discussion}

Coningham et al. have emphasised throughout their scholarship that the fine wares of southern India and Sri Lanka are the product of a single long-running major ceramic production centre' (Ford et al. 2005: 918); one that remained unaffected by the flourishing of Indian Ocean trade in the last centuries BC. Our analysis of the published geochemical data indicates that this is not the case. There are at least two geographically and chronologically distinct fine ware producing systems, the existence of which has serious ramifications for our understanding of the impact of seafaring trade across the Indian Ocean.

We concur with Coningham that prior to the second century BC, the production of fine wares was centralised within southern India and Sri Lanka. Greyware, the chronologically earlier ceramic of Group A, was produced in south-eastern India and exported to regional centres such as Anuradhapura in Sri Lanka. The movement of Greywares across some distance suggests that the authority of those consuming these elite wares extended well beyond the immediate settlement and had region-wide resonance. It is likely, but remains to be tested by further fieldwork, that these distribution networks reflect long-standing and 
deeply embedded social structures that shared processes of legitimisation across southern India and Sri Lanka.

Coningham $e t$ al. argue that this continues unabated into the second and first centuries BC. It is our contention that there was a bifurcation in Group A fine ware production in the second century $\mathrm{BC}$ that coincided with an intensification of maritime trade. This maritime trade was originally encouraged by economic growth under the Mauryan Empire (Ray 1994: 75-6; Schenk 2006: 140) but, as indicated by amphorae finds in India (Will 1996), included contact with the Mediterranean. Two fine ware traditions emerge, both of which contain similar geological inputs but different decorative - or visual - repertoires. One branch of Group A production is represented by IRW which is decorated in a fashion that clearly betrays foreign influence (Begley 1988: 440) while the other branch continues the Greyware production typical of the period before 200 BC. It is at this time that Group $\mathrm{B}$ production also emerges, characterised by IRW and Type 10 fine ware production in Sri Lanka.

Shifts in the consumption of fine wares after 200 BC, speak of new networks of exchange and production. Whereas Greyware continues to be produced at a single centre and exported to other cities such as Anuradhapura, and presumably Arikamedu, the IRW consumed at both of these sites is produced nearby and seems destined only for that city. In contrast to Greyware, the production and consumption of IRW is therefore regionalised. Although it is found at some inland sites, principally along river systems, it is mostly found at coastal settlements on the east coast of India suggesting a possible link to maritime trade (Schenk 2006). We suggest that the production of this new elite ware was linked to the emerging power of a new class of maritime merchants whose wealth and prestige was increasing but was still limited to the centres they inhabited and traded from. The lucrative nature of this trade is no more clearly indicated than by the rapid growth of Arikamedu in Phase $\mathrm{C}$ in the first century BC. At this time, a large reservoir was constructed and along the reservoir there operated a series of workshops which produced metal, glass, semi-precious stone, ivory and shell (Begley 1983: 472). This newly developed wealth can be contrasted to older existing forms of political-economy that were probably based on agrarian production.

That maritime merchants either traded or consumed IRW is indicated by its wide distribution across the Indian Ocean. From Berenike in Egypt (Tomber 2000) to Sembiran in Indonesia (Ardika \& Bellwood 1991), IRW is found at ports that supplied a range of consumable and luxury goods to and from India and the Mediterranean. IRW sherds with Tamil or Brahmi script graffito indicating ownership suggest that Indian traders were responsible for the distribution of this ceramic (Begley 1988: 430). That these merchants preferentially used or traded IRW over other south Asian fine wares is indicated by the corpus of south Asian fine wares found at distant trade sites. At Sembiran in Bali, for example, 117 of the 120 sherds of south Asian fine wares are of IRW; only two Type 10 sherds were found (Ardika \& Bellwood 1991).

The production of IRW may be defined, therefore, as a form of attached (Costin 1991) or tethered specialisation in which pottery was produced on demand for a specific group within society, in this case maritime merchants. This new elite ceramic was adorned with innovative and exotic decoration and would have not only served as a fine tableware but 
also, through its foreign-inspired decoration, communicated a differentiated social status at a time of increasing economic and social readjustment.

\section{Conclusion}

Careful and detailed analysis of the geochemical and archaeological data on the production of IRW in south Asia suggests a complex image of the social and economic change brought around by long-distance maritime trade. No scholar today would argue, as some claim Wheeler did, that south Asian society 'advanced' as a result of contact with the Mediterranean. Nor can it be argued that contact with the Mediterranean was a stimulus for the emergence of Indian Ocean trade. Such trade existed prior to Mediterranean contact and continued long after it dissipated. Contact with the Mediterranean, however, brought about changes in material culture production, at least at maritime sites and/or sites that were heavily involved with trade. In this paper we have hypothesised that the growing power of a new maritime merchant class led to attached production of a new elite ceramic, Indian Rouletted Ware. Although produced locally, this new pottery was decorated in a fashion that was deliberately foreign and thus referential to the importance of maritime trade as the economic basis for new social divisions within ancient south Asian society.

\section{Acknowledgements}

I would like to thank Prof. Alan Pollard (University of Oxford) for providing the geochemical data that is the focus of this paper. Prof. Rita Wright (Anthropology, NYU); Prof. Daniel Potts (Archaeology, University of Sydney); Prof. Don Barber (Geology, Bryn Mawr College); Dr Cameron Petrie (Archaeology, University of Cambridge); Dr Lloyd Weeks (Archaeology, University of Nottingham) and Dr Derek Kennet (Archaeology, University of Durham) read drafts of this paper. Two Antiquity reviewers provided invaluable feedback on this paper. I would like to thank them for the very useful comments - any errors that remain are my responsibility.

\section{References}

ARDiKA, I.W. \& P.S. BELLWOOD. 1991. Sembiran: the beginnings of Indian contact with Bali. Antiquity 65: 221-32.

Begley, V. 1983. Arikamedu reconsidered. American Journal of Archaeology 87: 461-81.

- 1988. Rouletted ware at Arikamedu: a new approach. American Journal of Archaeology 92: 427-40.

Costin, C.L. 1991. Craft specialization: issues in defining, documenting and explaining the organization of production. Archaeological Method and Theory 3: 1-57.

Dias M.I. \& M.I. PRUDÊNCIO. 2008. On the importance of using scandium to normalize geochemical data preceding multivariate analyses applied to archaeometric pottery studies. Microchemical Journal 88: 13-41.
ForD, L.A. \& R.A.E CONINGHAM. 2005. Early Historic specialisation and standardisation: the technology of Rouletted ware and associated wares at Anuradhapura, in U. Franke-Vogt \& H.J. Weishaar (ed.) South Asian archaeology, 2003: proceedings of the seventeenth international conference of the European association of south Asian archaeologists (Forschungen zur Archäologie Außereuropäischer Kulturen 1): 393-8. Aachen: Linden Soft.

Ford, L.A., A.M. POLlard, R.A.E. CONINGHAM \& B. STERN. 2005. A geochemical investigation of the origin of Rouletted and other related south Asian fine wares. Antiquity 79: 909-920, with online supplement available at: http://www.antiquity. ac.uk/projgall/ford306/ (accessed 24 May 2010).

GogTE, V.D. 1997. The Chandraketugahr-Tamluk region of Bengal: source of the Early Historic Rouletted ware from India and Southeast Asia. Man and Environment 22(1): 69-85. 
Krishnan, K. \& R.A.E. Coningham. 1997.

Microstructural analysis of samples of Rouletted ware and associated pottery from Anuradhapura, Sri Lanka, in F.R. Allchin \& B. Allchin (ed.) South Asian archaeology, 1995: proceedings of the thirteenth international conference of the European association of south Asian archaeologists, Cambridge, 5-9 July, 1995. Volume 2: 925-37. New Delhi: Oxford and IBH.

Morrison, K. 1997. Commerce and culture in south Asia: perspectives from archaeology and history. Annual Review of Anthropology 3: 215-37.

Prudêncio, M.I., M.I. Dias, M.A. Gouveia, R. Marques, D. Franco \& M.J. Trindade. 2009. Geochemical signatures of Roman amphorae produced in the Sado River estuary, Lusitania (western Portugal). Journal of Archaeological Science 36: 873-83.
RAY, H.P. 1994. The winds of change, Buddhism and the early maritime links of south Asia. New Delhi: Oxford University Press.

- 2003. The archaeology of seafaring in ancient south Asia. Cambridge: Cambridge University Press.

SCHENK, H. 2006. The dating and historical value of Rouletted ware. Zeitschrift für Archäologie Außereuropäischer Kulturen 1: 123-53.

TOMBER, R. 2000. Indo-Roman trade: the ceramic evidence from Egypt. Antiquity 74: 624-31.

WheEler, R.E.M., A. GHosh \& K. DeVA. 1946. Arikamedu: an Indo-Roman trading station on the east coast of India. Ancient India 2: 17-124.

WILL, E.L. 1996. Mediterranean shipping amphoras from the 1941-1950 excavations, in V. Belgley (ed.) The ancient port of Arikamedu: new excavations and researches 1989 to 1992 (Mémoires Archéologiques 22): 317-49. Pondichéry: Centre d'Histoire et d'Archéologie, Ecole Française d'Extreme-Orient. 